\title{
Agility for Sustainability in Zimbabwe: A Case Study for Manufacturing Companies in Bulawayo
}

\author{
William Msekiwa Goriwondo, Samson Mhlanga, Taonga Mutsambwa \\ NUST, Bulawayo, Zimbabwe
}

\begin{abstract}
Agility in manufacturing is critical for competitiveness. It is an ability to quickly change in a flexible way to meet market demand. This requirement has come as a result of the globalization phenomenon that has affected all companies in one way or the other. This study was aimed at establishing the level of agility that exists in Zimbabwean manufacturing companies. A case study of companies in Bulawayo with a focus on manufacturing diversity was conducted. Audits were carried out on a spectrum that covers textiles, beverages, pharmaceuticals, foundry, rubber manufacturing, including household and industrial chemicals. This enabled establishing the challenges that manufacturing companies face with a view of developing an appropriate model for agility and success. The current manufacturing practices were analyzed for selected companies while their ability to respond to market demand fluctuation was assessed and an appropriate model developed. The model incorporates characteristics of the local operating environment. The main challenges the manufacturing companies face in the global marketplace played a critical role in the development of the model. The manufacturing industry in Zimbabwe is stuck on mass production and traditional manufacturing practices. The world has changed and this change needs to be recognized as a vehicle for competitive success. Global competition has moved a step higher while companies in Zimbabwe have remained stagnant in their practices, technology, and agility. Many manufacturing companies elsewhere are employing agile manufacturing principles that drive them towards world class manufacturing status and sustainability in an ever-changing environment. Thus, the proposal for an agile manufacturing model for Zimbabwe is outlined.
\end{abstract}

Keywords: agile manufacturing, globalization, world class manufacturing, global competition

\section{Introduction}

Customer demand has greatly transformed from being general to a more individualistic one. Each customer has become more demanding in specific terms and is more inclined to choose to be treated as an individual entity defined by his/her own preferences. This has thus presented tremendous global competitive pressure on manufacturing companies. As such companies from all over the world need to be agile for them to remain competitive. The shift in customer demand patterns has put a shift on the way manufacturing companies should respond to demand and its associated dynamic and global nature.

William Msekiwa Goriwondo, MSc., MSOM, Department of Industrial and Manufacturing Engineering, NUST.

Samson Mhlanga, MSc., Advanced Manufacturing Systems (Brunel UK), Department of Industrial and Manufacturing Engineering, NUST.

Taonga Mutsambwa, BEng. IndEng, Department of Industrial and Manufacturing Engineering, NUST.

Correspondence concerning this article should be addressed to William Msekiwa Goriwondo, NUST, P.O.Box AC939, Ascot, Corner Cecil Av./Gwanda Road, Bulawayo, Zimbabwe. E-mail: wgoriwondo@gmail.com. 
Agile manufacturing is an approach to manufacturing which is focused on meeting the needs of customers while maintaining high standards of quality and controlling the overall costs involved in the production of a particular product (Yusuf \& Adeleye, 2002; Gunasekaran, Lai, \& Cheng, 2008). Agile is closely related to lean manufacturing which focuses on the reduction of as much waste as possible. Agility adds a new paradigm which proposes that customer demands need to be met rapidly and effectively. It enables manufacturing plants to adapt quickly to changes in market product preferences and volumes.

The concept of agility is defined in dictionaries as quick moving, nimble, and active. This differs from flexibility which implies adaptability and versatility. The difference between agility and flexibility is whether or not the change in market demand has been predicted. Flexibility refers to the capability of rapidly changing from one task to another when changing conditions are defined ahead of time. Agility refers to the ability to respond quickly to unanticipated market-place changes.

\section{Aim of the Research}

The aim of this project was to establish the level of agility of companies in Zimbabwe with focus on manufacturing companies in Bulawayo. The ultimate was to develop a conceptual model that could be applied to manufacturing companies including the Small and Medium Enterprises (SMEs).

\section{Related Literature}

Today's competitive global market is characterized by stringent business regulations, high operating costs, scarcity of resources, and unpredictable demand from increasingly informed customers. Agility has become a survival factor, hence, the need to develop organizations and facilities that are significantly more flexible and responsive than existing ones (Gould, 1997; James-Moore, 1996).

Agile manufacturing aims to develop agile properties (factories in this case) and human resources (agile workers). This agility is then used to rapidly respond to market through the ability to use and exploit the fundamental resource of knowledge (Cheng, Pan, \& Harrison, 2000; Uribe, Cochran, \& Shunk, 2003). This then becomes something that distinguishes successful and unsuccessful companies.

\section{The Manufacturing Sector in Zimbabwe}

Zimbabwe is a developing country that is one of the Southern African Development Community (SADC) countries (SIRDC, 2010). It has four basic sectors of the economy that generate wealth and these are: agriculture, mining, construction, and manufacturing (CZI, 2010). The manufacturing sector produces value-added products that are easily transferable across national and international borders. The country prides abundance of mineral resources and agricultural produce (Ndhlovu, Goriwondo, \& Mashingaidze, 2010), which form the bulk of raw materials to the manufacturing sector. CZI (2010) noted that there was a stabilization of economic activity following a decade of decline and revival of the manufacturing sector. The manufacturing sector which was once a dominant contributor to the GDP at $22 \%$ now contributes $17 \%$ (CZI, 2010). The manufacturing sector supplies $50 \%$ of its output into the agricultural sector whilst $63 \%$ of its input is obtained from agriculture. They convert these raw materials to more useful products that are value-added hence are of high value.

Bond and Masimba (2002) noted that, "a long period lies ahead in which damage done to a once strong industrial base must be repaired". This identifies the obvious need to revitalize the manufacturing base among other industrial concerns. This became the basis and major issue that was discussed and agreed upon in the 
Global Political Agreement (GPA) signed in 2008 by three major political parties in Zimbabwe (Zanu PF, Movement for Democratic Change (MDC), and the Movement for Democratic Change led by Morgan Tsvangirai (MDC-T)). The GPA required all political parties to work together in pursuit of a common goal that would see recovery of the Zimbabwean economy.

A report by the Scientific and Industrial Research and Development Centre (SIRDC) notes that, during the year 2000, manufactured exports accounted for $20 \%$ of total exports, whilst crude material including unprocessed food accounted for $24 \%$. This is not a sustainable situation since it drains money from the Zimbabwe resources. The country of origin for raw materials does not benefit economically (Ndhlovu et al., 2010) since value addition would be done outside the country of origin. SIRDC shares the same sentiments, and hence the need to have efficiency in raw materials transformation.

\section{Evolution of Manufacturing Systems}

The primary thrust in all manufacturing paradigms is to improve the company's operations so as to make it more profitable. It is noted that manufacturing has undergone many evolutionary changes and paradigm shifts that span from a craft industry to mass production, then to lean manufacturing, and currently to Agile Manufacturing (AM). The underlying principles of all manufacturing systems are the same but have been developed over years to facilitate improvements and adaptation to the ever-changing operating environment. The concepts of evolution of manufacturing systems are shown in Figure 1.

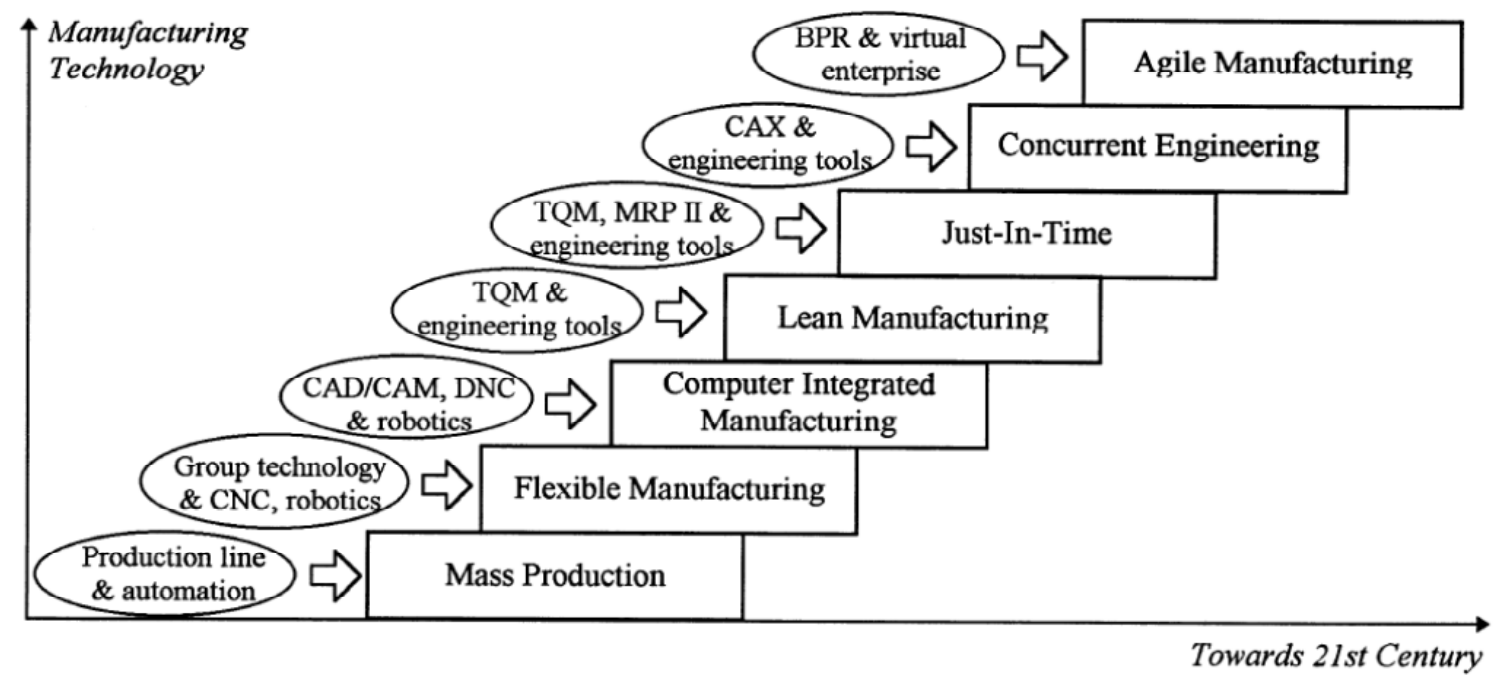

Figure 1. Evolution of manufacturing systems.

Another school of thought outlines the evolution from the 1850s to the 2000 era where lean manufacturing took centre stage (Strategos, 2005). The main gurus in this transformation of manufacturing systems are shown in Figure 2.

\section{Toyota Production System (TPS)}

Toyota Production System (TPS) was developed by Taiichi Ohno in the 1950s with the view of increasing profits by reducing cost. The two main pillars of TPS are Just-In-Time (JIT) and automation with a human touch. TPS works best in low variety and stable product demand environments, although modification to the original system has been developed for high-variety, low-volume environments. 


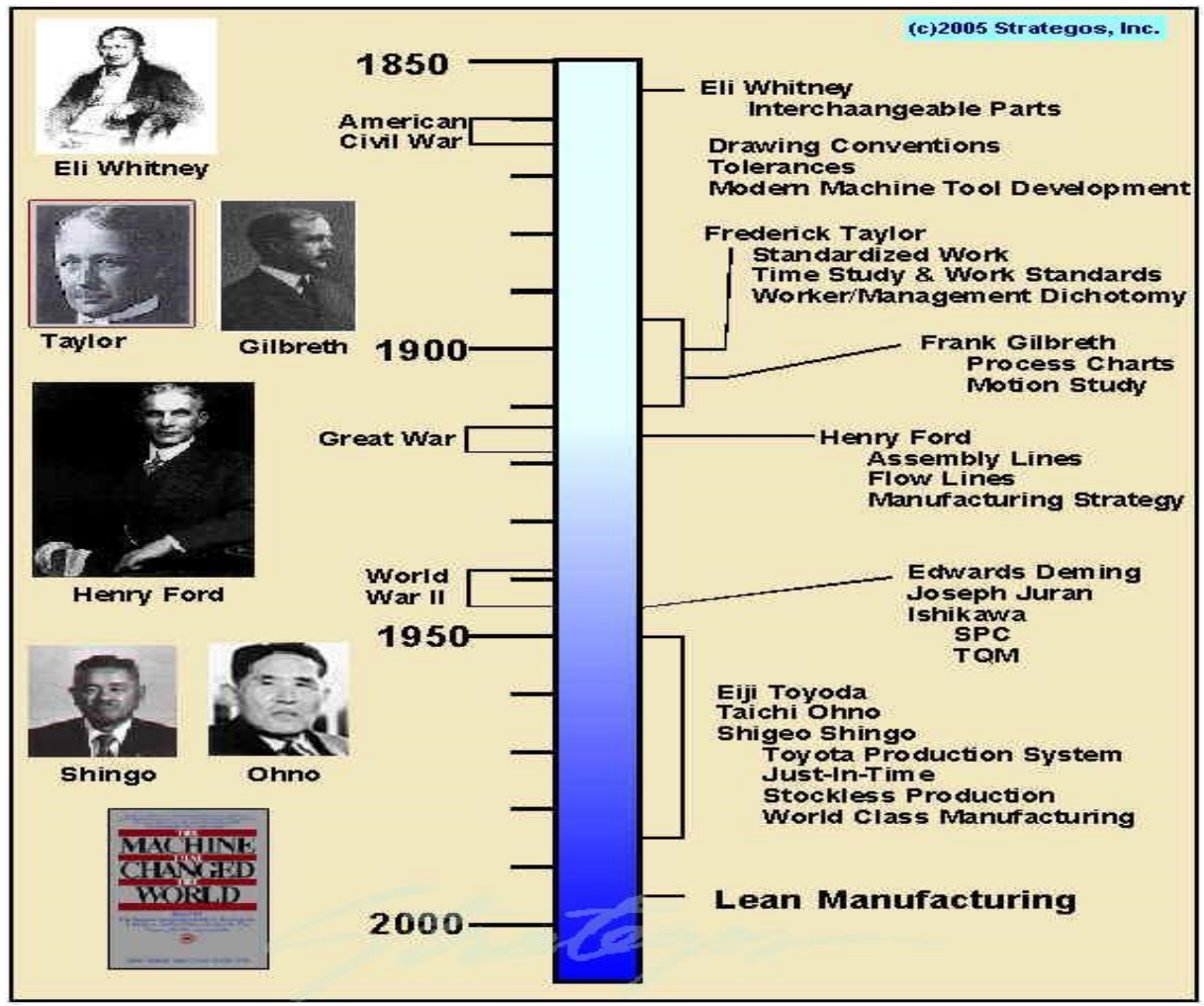

Figure 2. Transformation of manufacturing systems (Strategos, 2005).

\section{Lean Manufacturing}

Lean manufacturing is a philosophy and set of management techniques focused on continuously eliminating "waste" so as to remain with only "value adding" activities (the real output customer pays for) (Womack, Jones, \& Roos, 1990). It involves the extensive analysis of processes with the aim of waste-free production through identifying non-value-adding activities and subsequently eliminating them. It is a move from mass production to mass customization. Mass production puts much emphasis on individual efficiency while lean-thinking focuses on value-added flow and the efficiency of the overall system (Womack et al., 1991; Liker \& Lamb, 2000). The aspiration is to create a streamlined, high quality system that produces finished goods at the pace of customer demand with little or no waste (Kumar, Antony, Singh, Tiwari, \& Perry, 2006).

\section{Six Sigma}

Quality is one of the most important factors to consider when to do business as it is the way in which customers perceive products or services available. Six-sigma $(6 \sigma)$ is a statistical business-driven, multi-faceted approach to process improvement, cost-reduction, and increased profits. With a fundamental principle to improve customer satisfaction by reducing defects, its ultimate performance target is virtually defect-free processes and products. Six-sigma is today's most talked-about system for improving the quality of organizational processes (Oakland, 2003).

It helps every area of an organization to meet changing needs of its customers and increasing profitably as a result. Oakland (2003) defined six-sigma as "system of management to achieve lasting business leadership and top performance applied to benefit the business and its customers, associates, and shareholders". It is a goal for quality improvement that continually seeks to reach a near-perfection state. 


\section{World Class Manufacturing (WCM)}

The concept of WCM is not new but newly relevant due to globalization. The history of "world class" dates back to year 1984 when Hayes and Wheelwright (1984) coined the term. WCM developed from the history of best practices that describe new management styles and practices to increase organizations' global competitiveness (Prabhu, Yarrow, \& Gordin-Hart, 2000). Schonberger (1990) outlined the history of WCM by saying, "they came in 'waves' from the Far East during the 1970s and the early 1980s and have reshaped the way we think about and run our businesses". He highlights that the first of these was on "quality" during the late 1970s, followed by "Just in Time" (JIT) in the early 1980 and subsequently in the mid-1980s by people related practices, such as team-working and ownership, continuous improvement, and employee involvement.

Voss et al. (1995) defines WCM as "The point at which a certain standard in both practice and performance has been achieved... companies equal or surpass the very best of their international competitors in every area of business". Globalization opened up product floodgates to a global market with little or no protection of localized manufacturing companies.

World-class companies are those that withstand the test of time. There is a need for strategies that ensure continued survival and sustainability. Collins and Porras (1994) notices the main qualities required to achieve world-class status and they describe these as the "qualities of an enduring organization". There is a need for core value and core purpose, which are supported by dynamic strategies that suit the prevailing operating environment. This would enhance sustainable performance in the ever-changing global environment.

\section{Agile Manufacturing}

Agile manufacturing is a 21 century manufacturing paradigm that enables an organization to survive and prosper in a competitive environment where continuous and uninterrupted changes take place in a rapid manner (Cheng et al., 2000; Brown \& Bessant 2003; Uribe et al., 2003). Agile manufacturing is needed for situations such as turbulent business environment, intensified global competition, diversified demand, numerous new technology availabilities, and the utilization of such technologies (Jin-Hai, Anderson, \& Harrison, 2003; Calvo, Domingo, \& Sebastian, 2007; Gunasekaran et al., 2008). Enablers for agile manufacturing includes both managerial and technological (Wang, 2006). Many philosophies that have been developed now fall under enablers for agile manufacturing. These include both managerial and technological. The thrust for achieving agility lies in some strategies that allow an organization to become agile. These include redesign of organizational structure, value based pricing, and cooperation to enhance competitiveness (Gunasekaran et al., 1998; Sanchez \& Nagi, 2001).

\section{Methodology}

The study was conducted using a multiple case study approach. Organizational audits on the systems and operations in place were done on a spectrum of manufacturing companies that covers textiles, beverages, pharmaceuticals, foundry, rubber manufacturing, including household, and industrial chemicals.

The audits focused on evaluating how companies are performing to meet the four underlying principles of Agility (Goldman, Nagel, \& Preiss, 1995), which are delivering value to the customer, being ready for change in customer demands and needs, valuing and leveraging human knowledge and skills and strategies and virtual partnerships.

For each company, a radar chart was constructed based on the scores attained in the agility arms of delivering. 
The principles were scored in the following five fields:

- Strategic partnership;

- Customer response;

- Processes and systems response;

- Leveraging human skills and knowledge;

- Information technology and systems management and leveraging.

Each of the fields is scored against a 5 (with 5 being the most agile down to 0 , being the most none agile score).

Questionnaires were used to collect data followed by targeted interviews. The research sought to establish the extent to which a sample group of manufacturing companies has set its strategies, systems, technologies, and its people in order to quickly respond to customer needs and market changes. This was assessed alongside cost control and overall company effectiveness.

Data collected was processed and analysed to establish the level of agility and the focus of manufacturing companies in the case study. Data was then analysed and used to develop a conceptual model that is applicable to manufacturing companies including SMEs.

\section{Results and Analysis}

Results obtained were plotted into radar charts for each company studied. These are shown in Figures 3-9.

\section{Pharmaceutical Manufacturing Company}

From the radar chart in Figure 3, "leveraging of human skills and knowledge" and "strategic partnership" have a very high score, 4.4 and 3.8 respectively. These two fields have the highest performers for the pharmaceutical company. They however do not imply organizational agility. The other fields are still far below the minimum requirement like "process and system response" with a score of 0.6. It is the low performers that pull down the overall organizational agility standing.

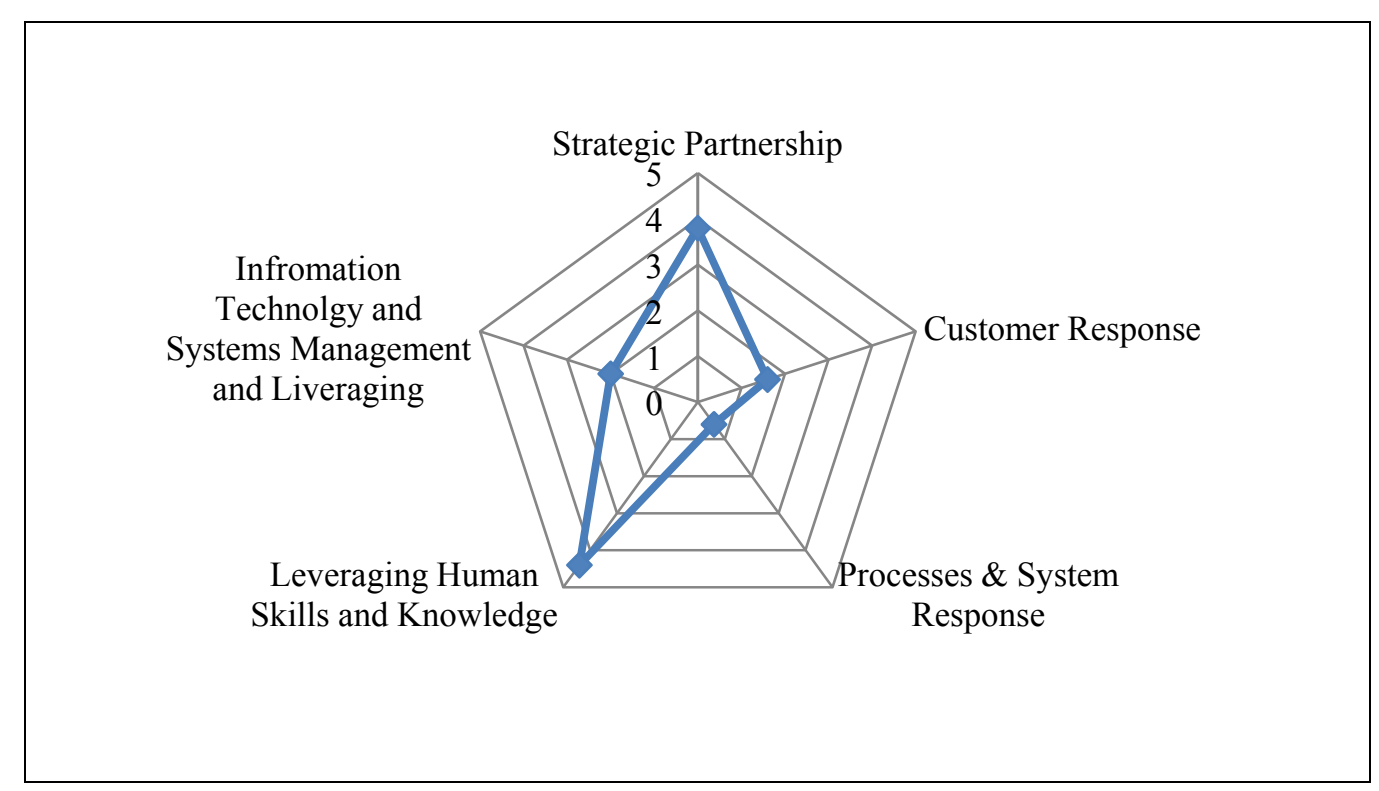

Figure 3. Pharmaceutical radar chart. 


\section{Beverages Manufacturing Company 1}

The radar chart in Figure 4 indicates how the beverages manufacturing company 1 has its main strengths in "leveraging human skills and knowledge" at 4.8 and "strategic partnership" at 4.2. Other fields are closely scattered around a score of 4 , this leave a shorter gap to achieve organizational agility.

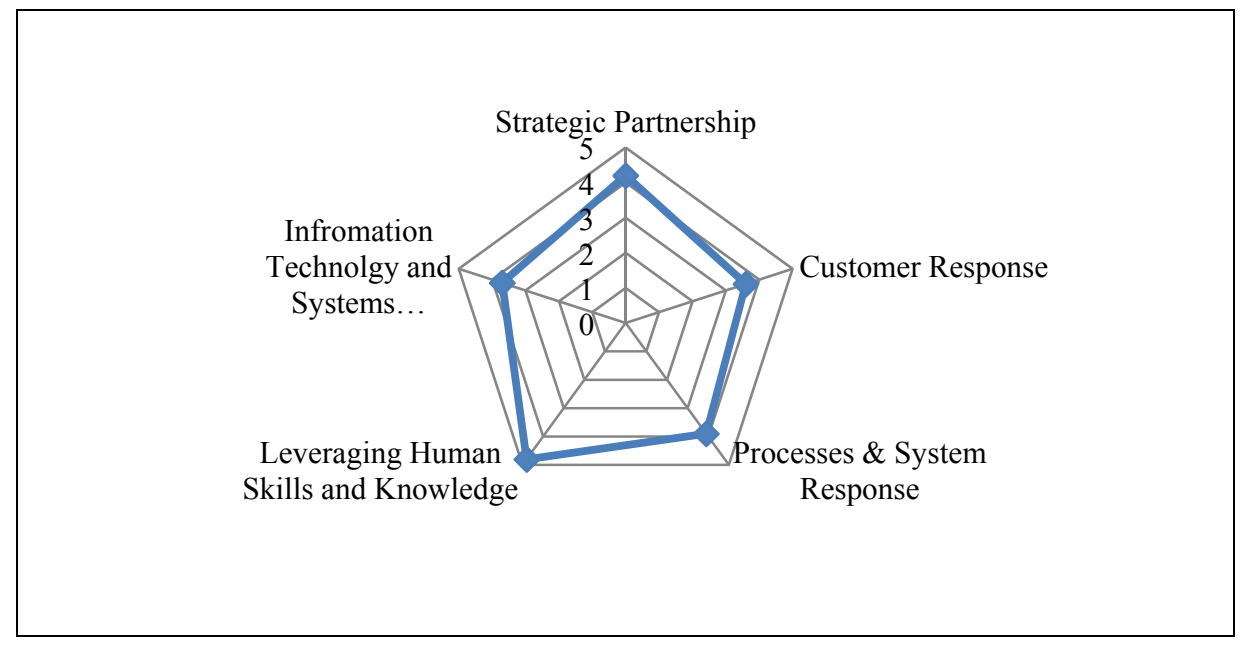

Figure 4. Beverages manufacturing 1.

\section{Beverages Manufacturing Company 2}

The Beverages Manufacturing Company 2 in Figure 5 is highly agile with only "customer response" scoring under a 4 with a 3.6 score. Its ability to utilize and train its labor force, investment in IT and new equipment and ownership of its resources/raw material enable it to effectively deliver its products, ensuring availability, and diversity of product range.

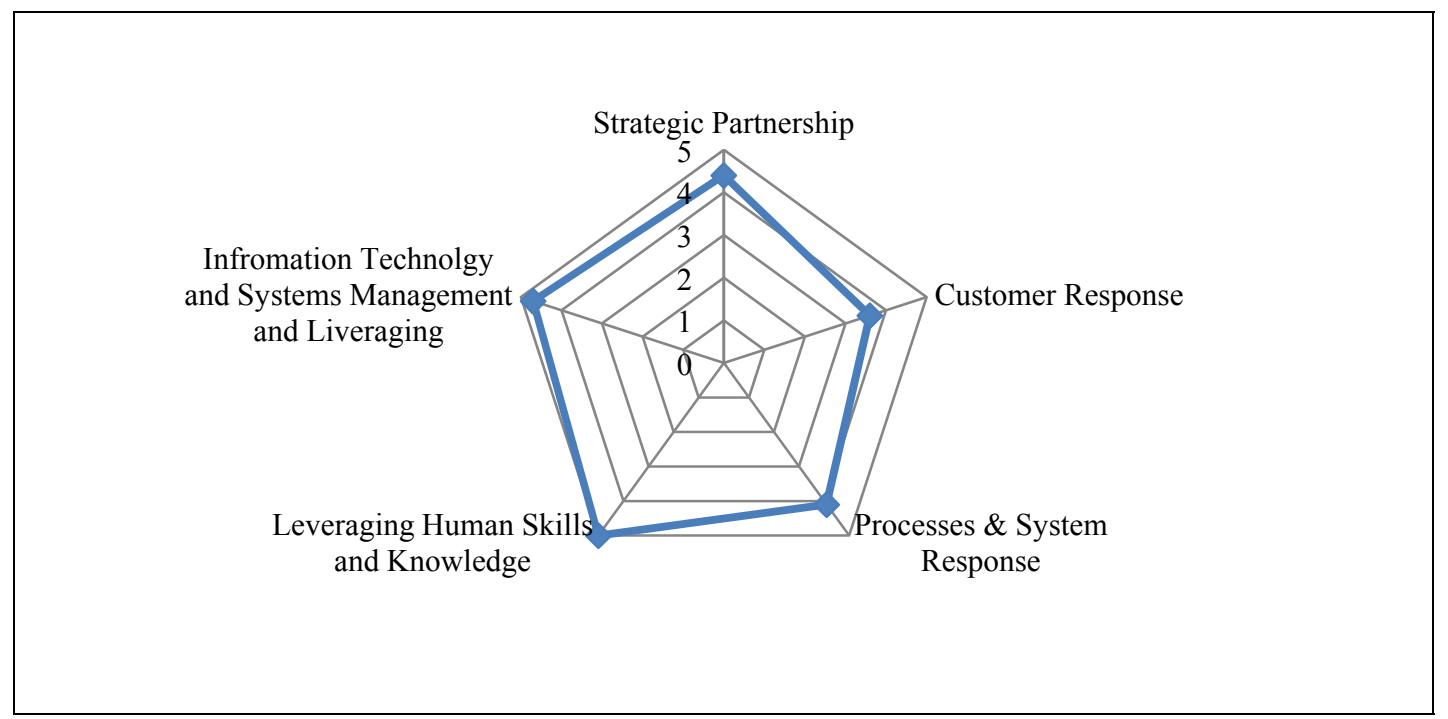

Figure 5. Beverages manufacturing 2.

\section{Chemicals Manufacturing Company}

The Chemicals Manufacturing Company's (see Figure 6) strength is "strategic partnership" at 4 though it looks as if is at the expense of "Leveraging Human Skills and Knowledge" due to the nature of its products. 


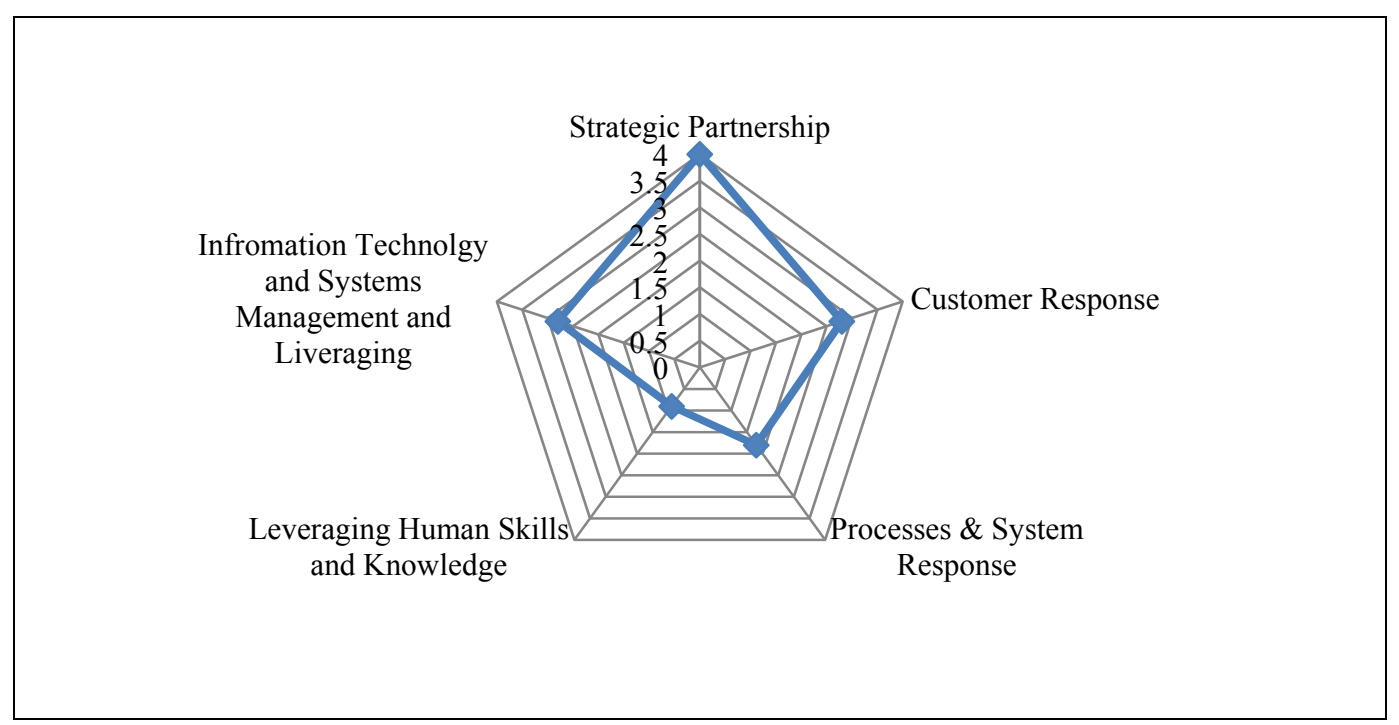

Figure 6. Chemicals manufacturing.

\section{Rubber Manufacturing Company}

The strength of Rubber Manufacturing (see Figure 7) at 2.2 in "customer response" is far below the minimum score of 4 expected for organizational agility. In essence, rubber manufacturing company is barely agile.

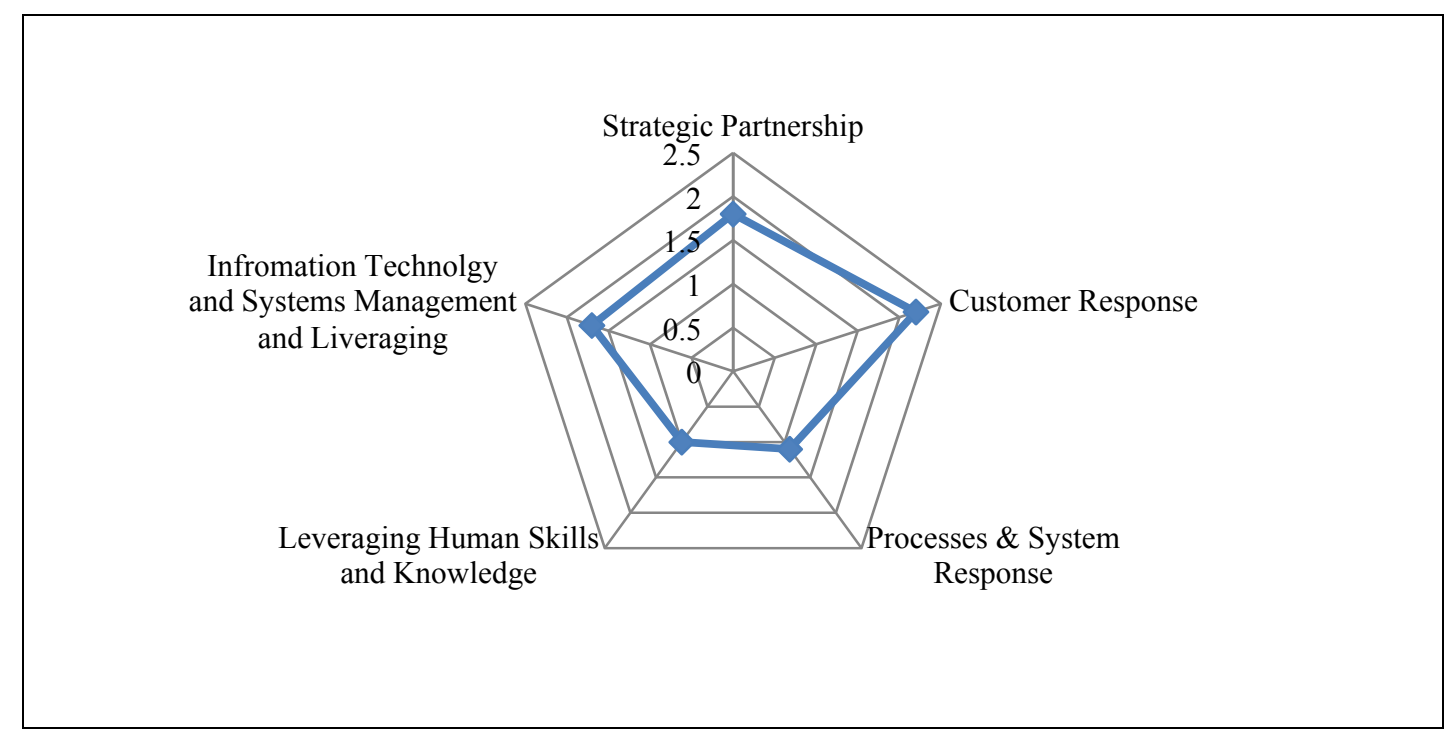

Figure 7. Rubber manufacturing.

\section{Foundry}

This radar chart (see Figure 8) is a reflection of a company with the means but is lax due to the confidence it has as a market leader where competition does not really exist.

\section{Textile Manufacturing Company}

Recent investments in equipment have only managed to improve "customer response" (scoring a 2.9) but 
only to an extent this may be hindered by the fact that the "strategic partnership" is significantly low (scoring just 1), hence, infringe the growth of all other fields with "leveraging human skills and knowledge" scoring less than 1 at 0.9 (see Figure 9).

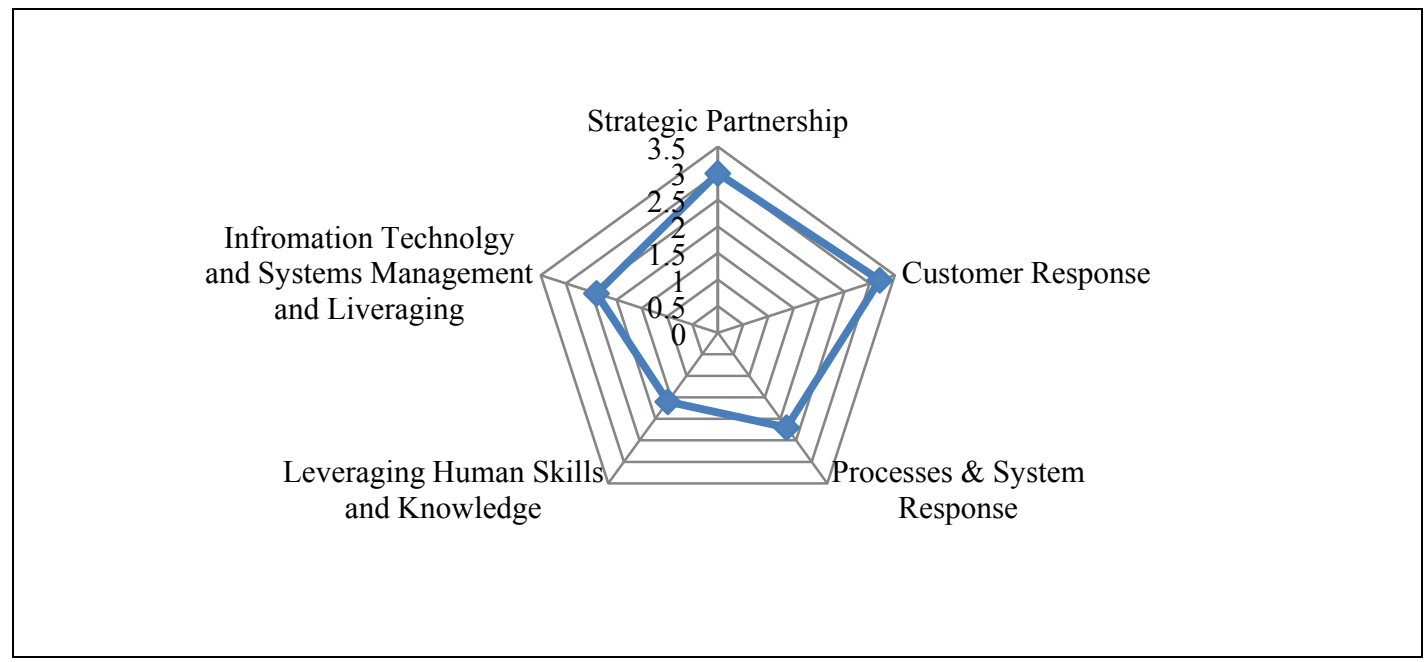

Figure 8. Foundry.

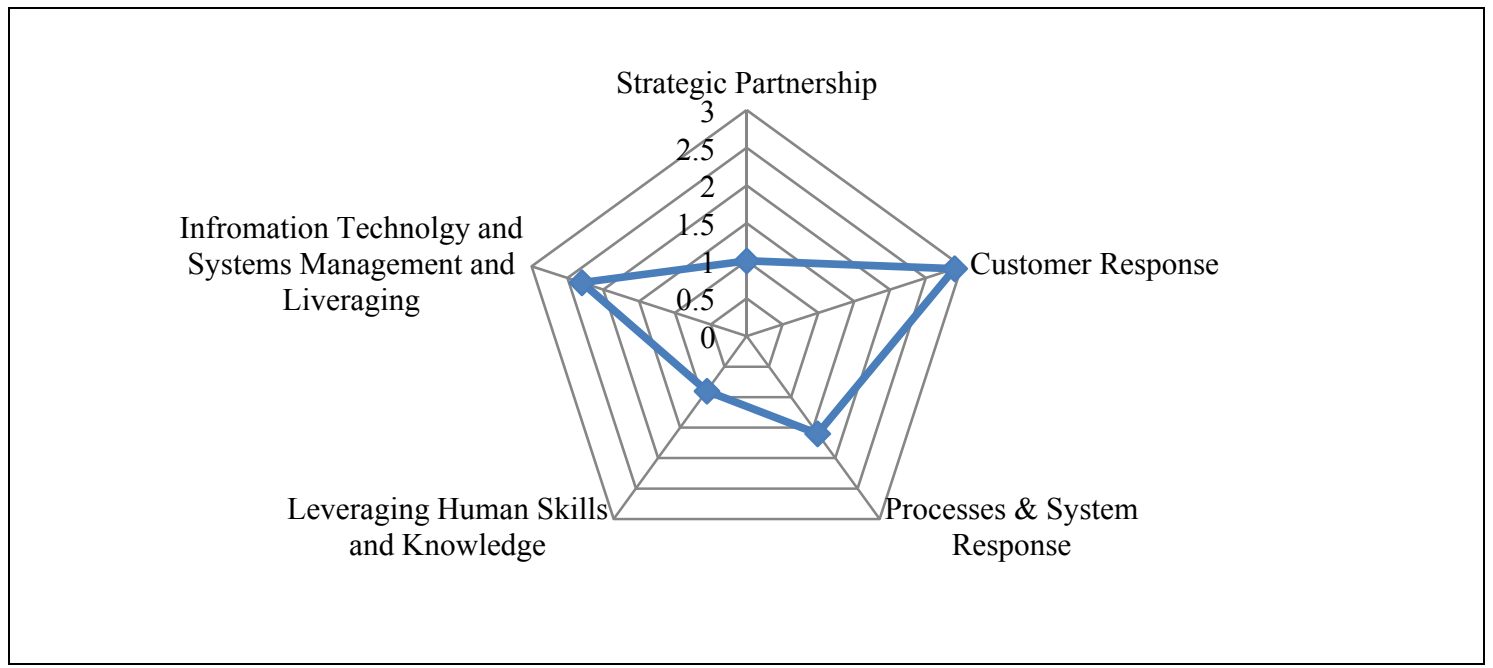

Figure 9. Textile manufacturing.

\section{Combined Industry Agility Results}

Table 1 shows the scores for all the assessed companies. The average for each agility arm is calculated and a radar chart is drawn and shown in Figure 10.

Using the individual organizational audit, an indicative result for the industry in Bulawayo can be drawn. It is meant to indicate where industry in the city of Bulawayo stands when it comes to agility. Table 1 shows the Bulawayo industry case study group indicative agility.

\section{Bulawayo Industry Strategic Partnership}

A score of 3.2 appears to be low, but in this study it has been pulled up by the capabilities and muscle of the beverages manufacturing companies. They have high scores in their individual capacities as a result of their 
supply chains. The score is influenced by the level of cooperation between suppliers and customers.

Table 1

Combined Assessment Scores for Agility for Case Study Companies

\begin{tabular}{|c|c|c|c|c|c|}
\hline Company & $\begin{array}{l}\text { Strategic } \\
\text { partnership }\end{array}$ & $\begin{array}{l}\text { Customer } \\
\text { response }\end{array}$ & $\begin{array}{l}\text { Processes and } \\
\text { system response }\end{array}$ & $\begin{array}{l}\text { Leveraging human } \\
\text { skills and knowledge }\end{array}$ & $\begin{array}{l}\text { Information technology } \\
\text { and systems management } \\
\text { and leveraging }\end{array}$ \\
\hline Pharmaceutical & 3.8 & 1.6 & 0.6 & 4.4 & 2 \\
\hline Beverages 1 & 4.2 & 3.6 & 3.9 & 4.8 & 3.7 \\
\hline Chemical manufacturing & 4 & 2.8 & 1.8 & 0.9 & 2.8 \\
\hline Rubber manufacturing & 1.8 & 2.2 & 1.1 & 1 & 1.7 \\
\hline Foundry & 3 & 3.2 & 2.2 & 1.6 & 2.4 \\
\hline Beverages 2 & 4.4 & 3.6 & 4.1 & 5 & 4.7 \\
\hline Textile & 1 & 2.9 & 1.6 & 0.9 & 2.3 \\
\hline Total score & 22.2 & 19.9 & 15.3 & 18.6 & 19.6 \\
\hline Average & 3.2 & 2.8 & 2.2 & 2.7 & 2.8 \\
\hline
\end{tabular}

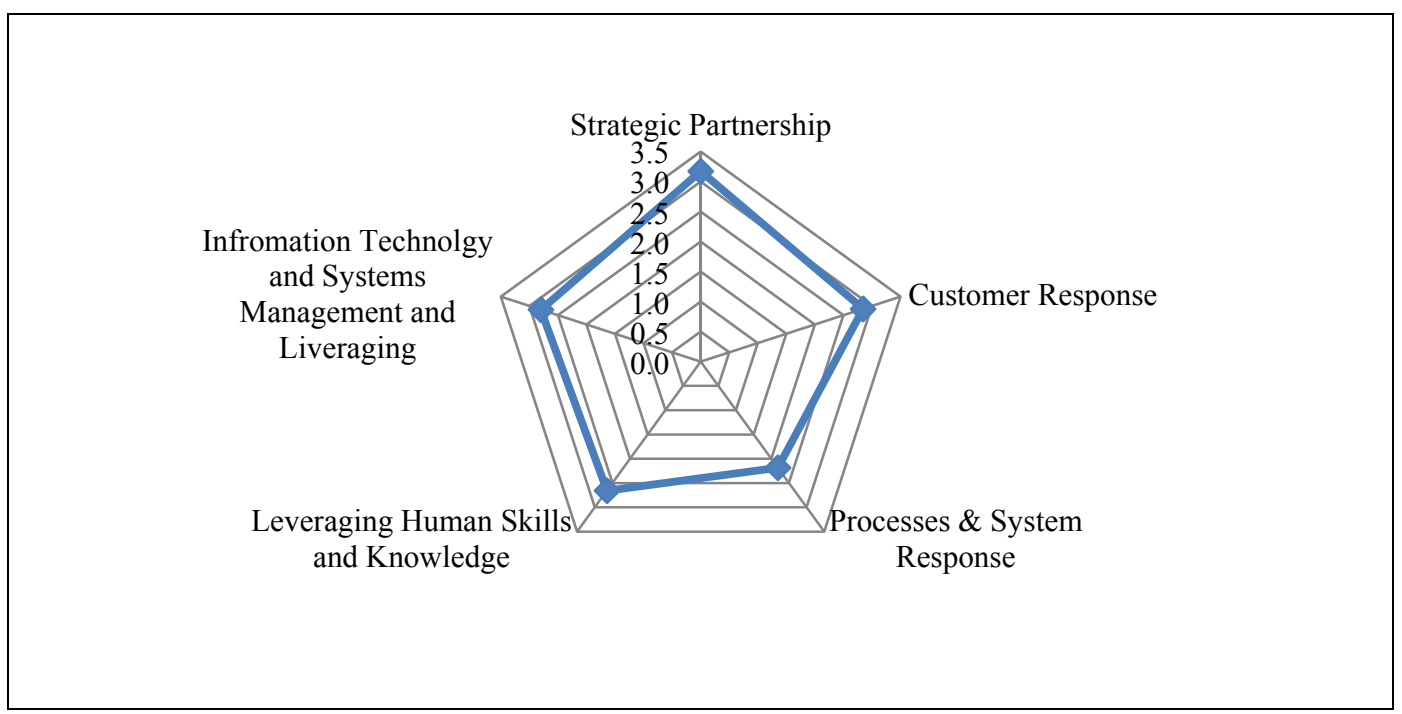

Figure 10. Consolidated radar chart for all sectors.

Under strategic partnership, the main consideration is on:

- Creation and use of temporary alliances to give the best value to the customer;

- Flexibility the ordering process;

- Involvement of suppliers in the product development process.

The challenge being faced by the Bulawayo industry is uncompetitive prices, questionable quality, and low capacity utilization. Most companies are importing raw materials, and this drives production cost to uncompetitive levels. This presents a set of complications that may hinder the full benefits of strategic partnership. The creation of temporary alliances becomes as suppliers need to consolidate their position and recover expenses. Importing reduces ordering flexibility and without adequate technology, involvement of suppliers in new product development is only imaginary and highly likely to be unattainable.

\section{Customer Response}

Customer response scores a 2.8 against the ideal score of a 5 . There seems to be little contact between the 
manufacturer and the customer. Contact with the customer is best implied when the price for a product is based on what the customer perceives as value. The erratic price changes and fluctuations indicate poor interaction with the customer. The concept of serving niche markets is currently neglected due to the high variability (high customization) of the orders.

\section{Industry Processes and Systems Response}

Processes and systems response score a 2.2. This indicates the company's ability to deal effectively and meet order size. There are issues of variability and complexity which could be dealt with by introducing better technology. This will result in the elimination of waste in processes and systems.

All the three categories are proving quite challenging across the board except for the beverages manufacturing companies. There may be a multitude of factors that can cause this and are outlined below:

- Inability to keep up with global trends due to ignorance;

- Use of old equipment (reworks, poor quality products);

- Maintaining tradition at the cost of efficiency (high prices for products);

- Inconsistent performance measurement;

- Absence of a research and development function.

Management training plays an important role in the effective exploitation of the systems in place. The training will enable management to challenge all systems and processes so as to improve efficiency and effectiveness.

\section{Leveraging Human Skills and Knowledge}

Currently, most of the training being received by the workforce is for new equipment. A chosen few go through this training as indicated in most organizational audits which suggest between $1 \%$ and $10 \%$ of the labor force go for further training. Lack of incentives or reward systems for employees to suggest innovative solutions to challenges in organizations was noted. This results in the inability of organizations to fully utilize its human resource. For example, in the textile industry, a pattern can cost up to $\$ 3,500$ in UK or USA, but if a worker bring in a pattern then he/she gets nothing for it but the company goes on to make $\$ 100,000$, this scenario, stops any future input from all employees. The failure of the company to acknowledge the worker's skill implies a loss in potential revenue and also:

- Poor introduction of innovative designs (poor customer satisfaction, no new products introduced);

- Poor process improvements (continual waste generation);

- Disgruntled and ill-motivated employees.

In the audit, "leveraging human skills and knowledge" score a mere 2.7 for the Bulawayo industry this is well below the possible score that can be attained

\section{Information Technology and Systems Management and Leveraging}

Information technology and systems management and leveraging are critical to all functions of agility. A lot of information is exchanged from market survey, customer, and suppliers' direct input during product development, ordering specifications, new concept introduction and feedback, current global trends, logistics, testing and simulation virtual manufacturing etc.. The absence of effective information system management and leveraging defeats any attempt to achieve agility in an organization. Most companies are avoiding investments in IT because of the certainty on return on investment, this fear is evident in how most companies are still using just telephone and if an employee is out of the office, his/her overall efficiency is significantly reduced or is at a 
standstill. In this regard, the Bulawayo industry scores a 2.8 .

\section{Conceptual Model}

Noting the challenges established in this research, a conceptual model to achieve agility was developed and is shown in Figure 11.

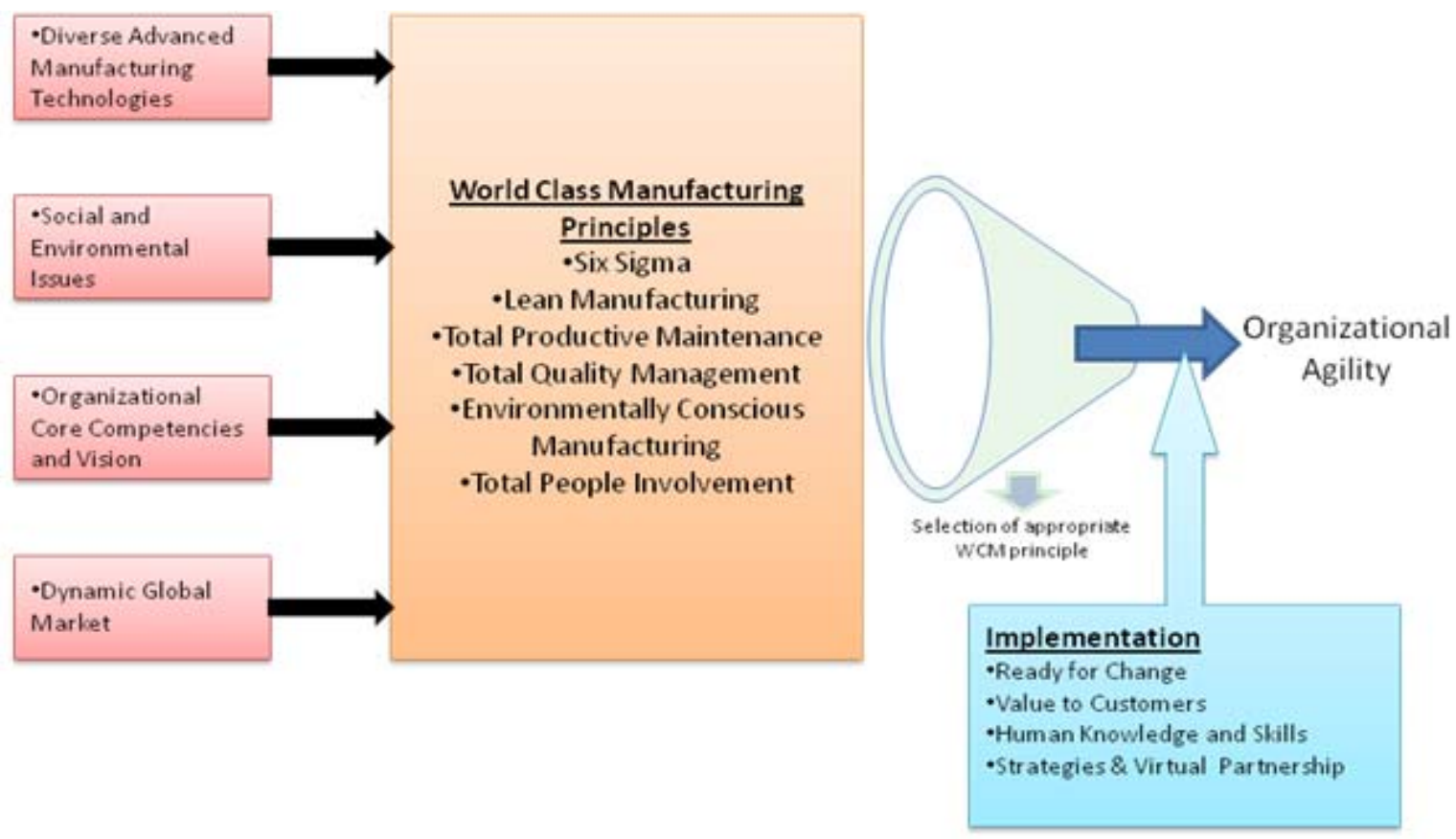

Figure 11. Conceptual model for agile manufacturing.

This model is based on the study results. It captures the need to know factors that affect agility and the key drivers. As such the appropriate world class manufacturing principles are taken through a selection process that caters for organizational culture and the company vision. With this focus, implementation of the appropriate principle(s) is driven with all people in the organization having been trained.

Organizational agility in manufacturing is achieved when the organization has developed strategic partnerships. Such partnerships help cut on inefficiency by other players along the supply chain who do not share the same vision as the organization. Customer response is critical since the customer determines the destination. If the organization responds appropriately to the customers, there is a good chance that there will be useful feedback that will promote continuous improvement.

Processes and systems response determines how the organization adapts to changes either in demand or in competing products. If required change takes long, competition will move in quickly and take away customers.

Total people involvement is a key element since the people in the organization are bound to own the system, agility will be achieved when the organization has high levels of leveraging on their knowledge and skills. Human capital potential is a key asset that the organization should utilize for agility.

Leveraging on information technology and systems management is also critical. It takes away the burden of using outdated technology against new and advanced technology. A company that employs advanced technologies will win competition. It will stay ahead in implementing new systems that are cost effective in a timely fashion. 


\section{Conclusions}

The manufacturing industry, the world-over, is facing challenges due to customer demand dynamics, the first one to successfully meet and satisfy these dynamics continually has established a competitive edge over his/her competitors. If also capable of meeting the dynamics and provide a product of good quality, at an acceptable cost, with high delivery speed as well as manufacture the product in the shortest time frame possible, the manufacturer has a competitive advantage over all his/her competitors. It is against this background that the authors endeavor to impart competitive advantage to the SMEs in Zimbabwe to ensure a global-competitive standing through the use of agile manufacturing. This model has been developed to enable SMEs to have small production runs with multiple product variety which match individual needs. It seeks to promote collaboration in place of specialization such that SMEs will lead to sustainability in manufacturing and effectively competing on the local then the global market.

\section{References}

Al-Hassan, K., Chan, J. F., \& Metcalfe, A. V. (2000). The role of total productive maintenance in business excellence. Total Quality Management and Business Excellence, 11(4), 596-601.

Bond, P., \& Masimba, M. (2002). Zimbabwe's plunge: Exhausted nationalism, neoliberalism and the search for social justice. Scottsville and London: University of Natal Press and Merlin Press.

Brown, S., \& Bessant, J. (2003). The manufacturing strategy capabilities links in mass customization and agile manufacturing-An exploratory study. International Journal of Operations and Production Management, 23(7), 707-730.

Calvo, R., Domingo, R., \& Sebastian, M. A. (2007). Systemic criterion of sustainability in agile manufacturing. International Journal of Production Research, 46(12), 3345-3358.

Carannante, T., Haigh, R. H., \& Morris, D. S. (1996). Implementing total productive maintenance: A comparative study of the UK and Japanese foundry industries. Total Quality Management and Business Excellence, 7(6), 605-612.

Cheng, K., Pan, P. Y., \& Harrison, D. K. (2000). The internet as a tool with application to agile manufacturing: A web-based engineering approach and its implementation issues. International Journal of Production Research, 38(12), 2743-2759.

Collins, J., \& Parras, J. (1994). Built to last. New York, N.Y.: Harper Collins.

Confederation of Zimbabwe Industries (CZI). (2010). Manufacturing sector survey. Retrieved December 14, 2012, from http://www. czi.co.zw/CZI_2010.pdf

Goldman, S., Nagel, R., \& Preiss, K. (1995). Agile competitors and virtual organizations. New York: Van Nostrand Reinhold.

Gould, P. (1997). What is agility. Manufacturing Engineer, 76(1), 28-31.

Gunasekaran, A., Lai, K., \& Cheng, T. C. E. (2008). Responsive supply chain: A competitive strategy in a networked economy. Omega, 36(4), 549-564.

Hayes, R. H., \& Wheelwright, S. C. (1984). Restoring our competitive edge: Competing through manufacturing. New York: Wiley.

James-Moore, S. M. R. (1996). Agility is easy, but effective agile manufacturing is not (p. 4). Proceedings of the IEE Colloquium (Digest), Oct. 26, No. 179.

Jin-Hai, L., Anderson, A. R., \& Harrison, R. T. (2003). The evolution of agile manufacturing. Business Process Management Journal, 9(2), 170-189.

Kumar, M., Antony, J., Singh, R. K., Tiwari, M. K., \& Perry, D. (2006). Implementing the lean six sigma framework in an Indian SME: A case study. Production Planning and Control, 17(4), 407-423.

Liker, J. K., \& Lamb, T. (2000). A guide to lean shipbuilding. Lean manufacturing guide, Version 0.5 (June 26, 2000), Maritech ASE Project \#10.

Mobley, R. K. (1990). An introduction to predictive maintenance. New York: Van Nostrand Reinhold.

Nakajima, S. (1988). Introduction to TPM: Total productive maintenance. Portland, O.R.: Productivity Press.

Ndhlovu, P., Goriwondo, W. M., \& Mashingaidze, M. M. (2010). Role of value addition to mineral resources in enhancing economic growth-A case for Zimbabwe (pp. 48-50). Proceedings of the 4th TWAS ROSSA Young Scientists' Conference on Science and Technology Enterprises in Africa. Nairobi: ICIPE Science Press.

Oakland, J. S. (2003). Statistical process control (5th ed.). Oxford: Butterworth Heinemann. 
Prabhu, V., Yarrow, D., \& Gordin-Hart, G. (2000). Best practice and performance within northeast manufacturing. Total Quality Management and Business Excellence, 11(1), 113-122.

Salaheldin, I. S., \& Eid, R. (2007). The implementation of world class manufacturing techniques in Egyptian manufacturing firms: An empirical study. Industrial Management and Data Systems, 107(4), 551-566.

Sanchez, L. M., \& Nagi, R. (2001). A review of agile manufacturing systems. International Journal of Production Research, 39(16), 3561-3600.

Schonberger, R. J. (1990). Building a chain of customers. London: Hutchinson Business Books.

SIRDC, A survey by SIRDC for UNIDO. (2010). Contribution of the manufacturing sector to sustainable development in $\begin{array}{lllll}\text { Zimbabwe. } & \text { Retrieved } & \text { September } & 23, & \text { from }\end{array}$ http://www.unido.org/fileadmin/import/userfiles/timminsk/rio10-ind-zimbabwe-eng.pdf

Strategos. (2005). Lean manufacturing historic timeline. Retrieved October 20, 2011, from http://www.strategosinc.com/lean_manufacturing_history.htm

Uribe, A. M., Cochran, J. K., \& Shunk, D. L. (2003). Two-stage simulation optimisation for agile manufacturing capacity planning. International Journal of Production Research, 41(6), 1181-1197.

Voss, C., Blackmon, K., Chase, R., Rose, B., \& Roth, A. V. (1995). The competitiveness of European manufacturing-A four country study. Business Strategy Review, 6(1), 1-25.

Wang, F. K. (2006). Evaluating the efficiency of implementing total productive maintenance. Total Quality Management and Business Excellence, 17(5), 655-667.

Womack, J. P., Jones, D. T, \& Roos, D. (1990). The machine that changed the world. New York: Rawson Associates.

Yarrow, D., Hanson, P., \& Robson, A. (2004). Made in the 21st century: How far have we come on the journey to excellence? Total Quality Management and Business Excellence, 15(5), 829-839.

Yusuf, Y. Y., \& Adeleye, E. O. (2002). A comparative study of lean and agile manufacturing with a related survey of current practices in the UK. International Journal of Production Research, 40(17), 4545-4562. 